NBER WORKING PAPER SERIES

\title{
A PERSONAL TOUCH: \\ TEXT MESSAGING FOR LOAN REPAYMENT
}

\author{
Dean Karlan \\ Melanie Morten \\ Jonathan Zinman \\ Working Paper 17952 \\ http://www.nber.org/papers/w17952 \\ NATIONAL BUREAU OF ECONOMIC RESEARCH \\ 1050 Massachusetts Avenue \\ Cambridge, MA 02138 \\ March 2012
}

We appreciate the cooperation of Greenbank and Rural Bank of Mabitac in designing and implementing this study. Thanks to John Owens and the staff at MABS in the Philippines for help with data and implementation mechanics. Thanks to participants at the Advances with Field Experiments 2011 conference for helpful comments. Thanks to Tomoko Harigaya, Rebecca Hughes, Mark Miller, Megan McGuire, and Junica Soriano for excellent field work, and to the Bill and Melinda Gates Foundation for financial support. The views expressed herein are those of the authors and do not necessarily reflect the views of the National Bureau of Economic Research.

NBER working papers are circulated for discussion and comment purposes. They have not been peerreviewed or been subject to the review by the NBER Board of Directors that accompanies official NBER publications.

(C) 2012 by Dean Karlan, Melanie Morten, and Jonathan Zinman. All rights reserved. Short sections of text, not to exceed two paragraphs, may be quoted without explicit permission provided that full credit, including $(\mathcal{C}$ notice, is given to the source. 
A Personal Touch: Text Messaging for Loan Repayment

Dean Karlan, Melanie Morten, and Jonathan Zinman

NBER Working Paper No. 17952

March 2012

JEL No. D21,D92,G21,O16,O17

\section{ABSTRACT}

We worked with two microlenders to test impacts of randomly assigned reminders for loan repayments in the "text messaging capital of the world". We do not find strong evidence that loss versus gain framing or messaging timing matter. Messages only robustly improve repayment when they include the loan officer's name. This effect holds for clients serviced by the loan officer previously but not for first-time borrowers. Taken together, the results highlight the potential and limits of communications technology for mitigating moral hazard, and suggest that personal obligation/reciprocity between borrowers and bank employees can be harnessed to help overcome market failures.

Dean Karlan

Department of Economics

Yale University

P.O. Box 208269

New Haven, CT 06520-8629

and NBER

dean.karlan@yale.edu

Melanie Morten

Yale University

27 Hillhouse Avenue

New Haven, CT 06511

melanie.morten@yale.edu
Jonathan Zinman

Department of Economics

Dartmouth College

314 Rockefeller Hall

Hanover, NH 03755

and NBER

jzinman@dartmouth.edu 


\section{Introduction}

We worked with two large Philippine microlenders, Greenbank and Mabitac, to test whether and how text message reminders can induce timelier loan repayment in a country that has been dubbed the "text messaging capital of the world". Each bank sent randomly assigned individual liability borrowers weekly text message reminders about their weekly repayment obligation. Additional levels of randomization varied the timing and content of the messages across borrowers. The timing treatment varied whether each message was sent on the due date, or on one or two days prior to the due date. The content treatments varied whether the message mentioned the loan officer's name, and whether the message was framed in loss or gain terms.

We do not find an overall treatment effect: there is no evidence that the average message improved repayment performance relative to the control group. The timing treatments do not have significant effects relative to the control group, or significant differences from each other. Nor does loss or gain framing produce significant improvements relative to the control group, or robustly significant differences from each other.

We do find that including the loan officer's name significantly improves repayment over relevant horizons. For example, the point estimate suggests that this type of text message reduces the likelihood that a loan was unpaid 30 days after maturity by 5.5 percentage points, a $41 \%$ reduction on a base of 0.135 . The effects of mentioning the loan officer's name are only significant for borrowers who entered the study having borrowed from the bank (and hence having been serviced by the same loan officer) before and the effects are significantly different for pre-existing borrowers compared to first-time borrowers. These results have implications for several different aspects of research and practice.

First, they add to the body of evidence on the existence and magnitude of ex-post (limited enforcement) frictions in credit markets (e.g., Adams, Einav, and Levin 2009; Karlan and Zinman 2009). The text messages do not change any contract terms between the borrower and the bank. Yet messages can induce repayment. This suggests that repayment is not fully contractible, and conversely that "repayment effort" (broadly

\footnotetext{
${ }^{1}$ See, for example, http://www.businesswire.com/news/home/20100823005660/en/ResearchMarkets-Philippines---Telecoms-Mobile-Broadband. Accessed 19 February 2012.
} 
defined to include safer project choice, effort as traditionally defined, and/or reduced strategic default) is elastic with respect to something other than the contract.

Second, the results shed some light on why or why not some types of messages might reduce ex-post frictions. We start with why not. Most message varieties here do not work, and there are only minor textual differences across the different varieties (see Table 1 for the scripts). Hence it seems doubtful that the messages here mitigated limited attention as a pure reminder, as postulated by the most closely related study. ${ }^{2}$ Nor does it seems likely that the messages provided informative signals about bank enforcement intentions; if that were the case, we might expect that all messages (all of which mention the bank name) would improve repayment relative to the no-message condition. And we would expect that including the loan officer's name in the message would have (relatively) strong effects on first-time borrowers, who probably have less precise expectations about bank and loan officer enforcement practices, whereas instead we found the reverse.

Our results do suggest a role for personal relationships between borrowers and loan officers. Perhaps (repeat) borrowers feel indebted (pun intended) to their loan officer, and the message triggers feelings of obligation and/or reciprocity (e.g., Cialdini and Goldstein 2004; Charness and Dufwenberg 2006) that increase repayment effort. This mechanism is distinct from the ones studied in the long literature on how soft information acquired by bank employees can help improve loan performance by reducing information asymmetries. That literature (e.g., Boot 2000; Agarwal et al. 2011) focuses on how additional (soft) information improves screening and/or monitoring. In contrast, our results suggest that messaging can improve repayment even without obtaining additional information on the borrower.

Third, our results shed light on optimal design of information and communications technology-driven development efforts (ICT4D). Research on ICT4D is only in its youth (e.g., Aker and Mbiti 2010; Donner 2008; Jack and Suri 2011), so unsurprisingly there

\footnotetext{
${ }^{2}$ Cadena and Schoar (2011) randomize whether individual microcredit clients in Uganda were sent an SMS, which in most cases was a picture of the bank, three days before each monthly loan installment was due. They do not randomize timing or content. Their messages improved timely repayment by $7-9 \%$ relative to the control group, an effect they benchmark, using pricing randomizations, as commensurate with effects of reducing the cost of capital by $25 \%$. Karlan et al (2011) and Kast et al (2012) find that text message reminders increase savings deposits among microfinance clients in four different banks across four different countries.
} 
has been relatively little focus on the mechanics (content, timing, etc.) of communications. Our findings suggest that content is critical, even within the constraints of a 160-character text message limit. Another interesting question is how technological innovations interact with local institutions. E.g., it seems intuitive to expect that, at least to some extent, economies of scale in ICT would favor larger, (trans-)national, transaction-based institutions over smaller, local, relationship-based institutions. Yet our results suggest that properly crafted ICT-based innovations can actually buttress relationship lending.

Our results come with a least two important caveats. One is that most of our null results are imprecise; our confidence intervals often do not rule out economically large effects in either direction, although we are able to reject equality of the effective treatments and the ineffective ones. The second is external validity. This is one of only two loan repayment message studies we know of, and taken together the two studies already present an important puzzle. Cadena et al find that an SMS image of their bank does increase repayment on average. We do not find that text messages mentioning the bank increase repayment on average. Is this difference due to variation across the two studies in borrower characteristics? In credit market characteristics? In ICT market characteristics? In lender practices? These questions highlight the need for formulating and testing different theories about mechanisms underlying messaging effects, and for testing these theories within settings when theory predicts such heterogeneity, and across different settings when theory predicts differential effects across underlying contextual factors and market conditions.

The rest of the paper proceeds as follows. Section 2 describes the setup of the experiment. Section 3 presents the results and discussion. Section 4 briefly concludes.

\section{Experimental Setting and Design}

We worked with two for-profit banks to design and implement an SMS loan repayment experiment on individual liability microloan borrowers, Green Bank and Mabitac. Green Bank operates in both urban and rural areas of the Visayas and Mindanao regions. It is the 5th largest bank by Gross Loan Portfolio in the Philippines. ${ }^{3}$ Mabitac

\footnotetext{
${ }^{3}$ Source: www.mixmarket.org, accessed 2/7/2012.
} 
operates in both urban and rural areas of the Luzon region. It is the 34th largest bank in the Philippines. Both banks are among the leading microlenders in the Philippines.

The Philippines is a suitable environment for a study of responses to SMS messaging. Anecdotally known as the "texting capital of the world", cellphone use is widespread: $81 \%$ of the population had a cellphone subscription in $2009,{ }^{4}$ and texting is an especially popular method of communication because of its low cost, generally about 2 cents a message. Approximately 1.4 billion SMS are sent by Filipinos each day.

We lack much demographic data on the specific borrowers in our sample, but prior work with a different bank with similar microfinance operations suggests that borrowers are likely predominantly middle-aged female microentrepreneurs, and likely about average with respect to education and household income relative (Karlan and Zinman 2011). This other bank however is located in urban and peri-urban Manila, versus the urban and rural setting of the two partner banks from this study.

Summary statistics for the loans in our sample are presented in Table 2. The average loan is approximately \$400 USD, repaid weekly over a 16 to 20 week term at around $30 \%$ APR. Microloan charge-off rates are typically around 3\% for the banks in this study.

Late payments are common: $29 \%$ of weekly loan payments are made at least one day late in the control group, and $16 \%$ are a week late. $14 \%$ of loans are not paid in full within 30 days of the maturity date. Late payments and delinquencies are costly for the banks because they trigger additional monitoring, accounting, and legal actions. Mabitac begins actively following up on late payments 3 days after the due date, while Greenbank begins after 7 days. Late payments and delinquencies can also be costly for the borrower: borrowers are charged late fees, may be subject to legal action, and their creditworthiness and ability to secure future loans is decreased. So the focus of the experiment was to improve timely repayment of the weekly loan installments.

We designed the experiment to test the effects of three different dimensions of a messaging strategy. One dimension is whether to send messages at all: borrowers were assigned to either treatment (receive a message weekly, for the entire loan term) or control (no message).

\footnotetext{
${ }^{4}$ Source: World Bank Development Indicators Database; accessed 8/27/2011.
} 
A second dimension is messaging content. Each message was randomly assigned a $2 \times 2$ combination of "loss vs. gain framing" and "personalization", producing the four scripts shown in Table 1. All message variants included some boilerplate content: the bank name, "pls pay your loan on time", and "If paid, pls ignore msg. Tnx". Loss-framed messages started with "To avoid penalty...". Gain-framed messages started with "To have a good standing...". The personalization treatment varied whether the client's name ("From [bankname]: [client name],...) or the account officer's name ("From [AO's name] of [bankname]:...") was included in the first 2 or 3 words of the message.

The third dimension tested here is timing: we randomly and independently varied whether each of the borrower's messages were sent 2 days before the scheduled payment date, the day before the scheduled payment date, or the day of the scheduled payment date. ${ }^{5}$ Borrowers received the same content and timing each week, for the term of the loan; i.e., we randomized at the loan level. ${ }^{6}$

Our study sample includes 943 loans originated by Greenbank and Mabitac between May 2008 and March 2010, and captures about half of the individual liability microloans made by the two banks during this period where the client provided a cellphone number to the lender. We include only the first loan per client during this time period because a treatment that affects repayment on the first loan in turn affects the likelihood of subsequent loans. We exclude first loans where bank reporting errors made it impossible for us to randomize messaging or to match randomly assigned loans to bank data on loan repayment. $^{7}$

\footnotetext{
${ }^{5}$ The randomization was set to $33 \%$ for control and $66 \%$ to treatment, equally divided between the 4 treatment groups. The timing treatment was independently randomized, with each three treatments equally likely. However, due to a coding error the final breakdown of randomization was $34 \%$ treatment, and then $12 \%, 25 \%, 14 \%, 15 \%$ to each of the four treatments instead of $17 \%$ each treatment group. There was no error in coding the independently randomized timing treatment. Table 2 tests for balance across treatment arms in baseline loan characteristics, and we find no evidence of imbalance.

${ }^{6}$ Other mechanics of the randomization: the research team received weekly reports of clients with payments due in the following week from each participating branch. We randomized clients the first time they appeared in these weekly reports. Once randomized into treatment, clients received weekly text messages until their loan maturity date. The text messages were automatically sent using SMS server software.

${ }^{7}$ We randomized a total of 1703 loans. 138 loans were not reported to us until nearly the end of their repayment cycle. Another 305 loans that did get random assignments could not be matched to repayment data because one of the banks changed its database midstream and did not create a
} 
The top three rows of Table 2 check whether the characteristics of the 943 loans in our study sample are balanced across control $(\mathrm{N}=312)$ vs. treatment $(\mathrm{N}=631)$, vs. each content treatment arm (total $\mathrm{N}=631$ ), and vs. each timing treatment arm (total $\mathrm{N}=631$ ). The three characteristics we observe for each loan are amount, term, and number of weeks in our experiment (this number of weeks equals the number of weekly repayment observations we observe for that loan, and also the number of messages a treated loan was sent). None of the pairwise comparisons between control and treatment produce a statistically significant difference (differences not shown in table). We also regress treatment assignments on the three loan characteristics and fail to reject equality in each of the six regressions; as the table shows, the smallest p-value in any of those regressions is 0.17 .

\section{III.Treatment Effects of Messaging on Loan Repayment}

The bottom panel of Table 2 presents simple means comparisons for outcome data: five different measures of late loan repayment. Stars indicate a pairwise significant difference between a treatment arm and the control group. These comparisons preview one of our main regression results from Section 3 below: only the messages containing the account officer's name reliably reduce delinquency relative to the control group. We find large and statistically significant reductions for all five measures. ${ }^{8}$

We also estimate treatment effects using OLS equations of the form:

$Y_{\mathrm{it}}=\alpha+\beta T_{\mathrm{i}}+\delta X_{\mathrm{i}}+\varepsilon$

Where $Y$ is a measure of late payment for loan (or, equivalently, client) $\mathrm{i}$ at time t. $T$ is either an indicator for whether messages were sent for this loan, or the complete vector of

unique identifier for tracking/matching loans across the old and new database. Treatment assignment is uncorrelated with whether we could match to administrative data (p-value 0.53). One loan was randomized twice, and 316 loans were subsequent loans of clients already in our study and hence dropped from the final analysis. This leaves a final sample of 943 loans.

${ }^{8}$ We also use an alternative measure of late payment: whether the client missed a payment in the calendar week, defined as Sunday-Saturday. If loan payments are made late they are applied to the most outstanding installment first, so this alternative measure could capture whether a client is making regular payments even if they remain in arrears. Under this measure, no payment is made at all in $19 \%$ of weeks when a payment is due. The empirical results are robust to using this alternative measure of late payment (Appendix Table 1). 
treatment categories capturing assignment to one of the four content arms (loss or gain $\mathrm{X}$ client name or AO name) and to one of the three timing arms. In either setup the control group is the omitted category for $T . X$ is a vector of account officer and month-year (of the $Y$ observation) fixed effects. In specifications where we have multiple weekly observations per loan we cluster the standard errors by loan.

Table 3 presents results for three different measures of late repayment (three more are considered in Appendix Table 1). Late and More Than 7 Days Late are based on the timeliness of the required weekly payments; for these outcomes the unit of observation is the loan-week, and we only include weeks starting with the week a bank first reported a loan to us and we randomly assigned that loan to treatment or control. The other outcome, Late 30 Days After Loan Maturity, is measured at a single point in time, and hence the unit of observation is the loan.

The first cell in each block in Table 3 presents the estimated treatment effect of receiving any messaging on each of the three outcomes. None of the point estimates are statistically significant, but all three are negative (indicating reduced delinquency) and the confidence intervals do not rule out economically meaningful effects (the control group means are reproduced near the bottom of the table for reference/scaling).

Focusing on Panel A of Table 3, the next four rows present treatment effect estimates for each of the four content combinations relative to the control (no messaging) group. Neither of the client name messages (whether gain- or loss-framed) produced statistically significant effects, and five of their six coefficients are positive (indicating increased delinquency).

Appendix Table 2 presents results for loss- and gain-frame relative to control (grouping the loss-frame bank-named with the loss-framed account officer-named message, etc.). None of the six coefficients are significantly different from the control group, although there is a bit of evidence that negative framing is (more) effective: all three of its coefficients are negative, and the p-values on the difference between negative and positive framing are $0.08,0.19$, and 0.26 .

Returning to Panel A of Table 3, we see that each of the six estimates for account officer-(AO-) named messages (whether gain- or loss-framed) indicate late and missed weekly payments. The positive-frame AO coefficient is negative and significant in all 
three cases. The third column in each block presents a dummy for any message with the AO name. This is also negative and statistically significant in three cases. In each case the point estimate on the AO-named message dummy implies substantial reductions: $24 \%$ in late payments, $34 \%$ in 7 days late, and $41 \%$ in unpaid 30 days after maturity. Conversations with bank management indicate that reductions of these magnitudes would produce cost savings that greatly exceed the cost of messaging.

What explains the effectiveness of the AO messages? The fact that repayment responds to messaging at all suggests the presence of some sort of limited enforcement/moral hazard; i.e., of some sort of elasticity of repayment effort (broadly defined to include strategic default and perhaps project choice; see, e.g., Karlan and Zinman (2009)) that is not captured by observable risk and that hence is not priced on the margin. A more precise question is how the $\mathrm{AO}$ message triggers increased borrower repayment effort and thereby mitigates moral hazard. Prior work suggests two possible channels. Work on relationship lending suggests that the AO message may signal increased intent to monitor the borrower (screening/selection is not in play here, since loans are not assigned to treatment until after origination). Work on social obligation and reciprocity suggests that the $\mathrm{AO}$ message may trigger better behavior from borrowers who have a relationship with the $\mathrm{AO}$ in the lay sense (not the asymmetric information sense): a personal or professional relationship.

Table 4 explores whether the $\mathrm{AO}$ messages operate on borrower monitoring expectations and/or lay-sense relationships by running the analysis separately for clients who entered the sample as first- time borrowers with the bank vs. for clients who entered the sample as pre-existing borrowers with the bank. (We continue here to limit our analysis to the first loan a borrower obtained during the time period when we were randomizing.)

Our hypothesis is that new borrowers know less about AO monitoring than experienced borrowers, and hence that new borrowers should infer more from the AO message if in fact the message works by signaling intent to monitor closely. So if the message works by changing expectations about monitoring, we would expect greater reductions for first-time borrowers. Table 4 shows that the opposite is true. The AO message produces significant reductions only for repeat borrowers, and although the 
confidence intervals for the first-time borrowers sub-sample do not rule out significant reductions (or increases) in delinquency, the differences in the AO message treatment effects across the two sub-samples are statistically significant in all 3 cases. It seems that the AO-named message is actually more powerful for pre-existing borrowers, suggesting that it is the "personal touch" and not signaling that matters. This interpretation makes sense considering that nearly all repeat borrowers (an estimated 80\%) have the same loan officer across loans.

Returning to Table 3, Panel B presents treatment effect estimates for the timing treatments relative to control. Clients assigned to messages were sent them every week, on either: the day the payment was due, the day before, or 2 days before. This timing treatment was independently randomized after the initial randomization to either the control group or one of the four message scripts. We do not find any statistically significant evidence that a specific timing treatment is effective relative to control, or relatively effective compared to the other timing treatments.

\section{Conclusion}

This paper presents the results of a simple randomized trial sending text messages to individual liability microfinance clients from two banks in the Philippines. We do not find an overall treatment effect: the average message does not significantly improve repayment. Nor do we find strong evidence of (differential) impacts from loss vs. gain frames or message timing. However, messages that mention the loan officer's name significantly, substantially, and robustly improve repayment rates relative to messages that mention the client's name and/or to the no-message control group. This effect is only significant, and significantly stronger, for clients who enter the sample having borrowed from the bank (and hence been serviced by the loan officer) before, suggesting that the messages trigger feelings of social obligation/reciprocity. That is messages seem to work by triggering personal relationships rather than by signaling intent to monitor closely.

This study highlights several directions for future research. One is the importance of replication, ideally with large samples that permit sharper inferences on null effects. A second is further interplay between theory and empirics about when, why, and how messaging content matters. A third is further exchange between theory and empirics 
about when, why, and how the effects of messaging and ICT differ across different market and cultural settings. A fourth is on the interaction between ICT and personalization. The study here suggests that there need not be a trade-off between technology and personalization; indeed, it may be the case that attuning ICT to personal relationships can reinforce relationship lending as traditionally defined. 


\section{References}

Adams, William, Liran Einav, and Jonathan Levin. 2009. "Liquidity Constraints and Imperfect Information in Subprime Lending." American Economic Review 99 (1) (March): 49-84.

Agarwal, Sumit, Brent Ambrose, Souphala Chomsisengphet, and Chunlin Liu. 2011. "The Role of Soft Information in a Dynamic Contract Setting: Evidence from the Home Equity Credit Market." Journal of Money, Credit and Banking 43 (4) (June): 633-654.

Aker, Jenny, and Isaac Mbiti. 2010. "Mobile Phones and Economic Development in Africa." Journal of Economic Perspectives 24 (3): 207-232.

Boot, Arnoud. 2000. "Relationship Banking: What Do We Know?" Journal of Financial Intermediation 9 (1): 7-25.

Cadena, Ximena, and Antoinette Schoar. 2011. "Remembering to Pay? Reminders Vs. Financial Incentives for Loan Payments." NBER Working Paper 17020 (May).

Charness, Gary, and Martin Dufwenberg. 2006. "Promises and Partnerships." Econometrica 74 (6) (November): 1579-1601.

Cialdini, Robert, and Noah Goldstein. 2004. "Social Influence: Compliance and Conformity." Annual Review of Psychology 55: 591-621.

Donner, Jonathan. 2008. "Research Approaches to Mobile Use in the Developing World: A Review of the Literature." The Information Society 24 (3): 140-159.

Jack, William, and Tavneet Suri. 2011. "Mobile Money: The Economics of M-PESA." NBER Working Paper No. 16721 (January).

Karlan, Dean, Margaret McConnell, Sendhil Mullainathan, and Jonathan Zinman. 2011. "Getting to the Top of Mind: How Reminders Increase Saving". Working Paper.

Karlan, Dean, and Jonathan Zinman. 2009. "Observing Unobservables: Identifying Information Asymmetries with a Consumer Credit Field Experiment." Econometrica 77 (6): 1993-2008.

- 2011. "Microcredit in Theory and Practice: Using Randomized Credit Scoring for Impact Evaluation." Science 332 (6035) (June 10): 1278-1284.

Kast, Felipe, Stephan Meier, and Dina Pomeranz. 2012. "Under-Savers Anonymous: Evidence on Self-help Groups and Peer Pressure as a Savings Commitment Device." 
TABLE 1. Wording of text messages

\begin{tabular}{|c|l|l|}
\hline \multirow{3}{*}{ AO name } & Positive & $\begin{array}{l}\text { From [aoname] of [bankname]: To have a good standing, } \\
\text { pls pay your loan on time. If paid, pls ignore msg. Tnx }\end{array}$ \\
\cline { 2 - 3 } & Negative & $\begin{array}{l}\text { From [aoname] of [bankname]: To avoid penalty pls pay } \\
\text { your loan on time. If paid, pls ignore msg. Tnx. }\end{array}$ \\
\hline \multirow{2}{*}{ Client name } & Positive & $\begin{array}{l}\text { From [bankname]: [name], To have a good standing, pls } \\
\text { pay your loan on time. If paid, pls ignore msg. Tnx. }\end{array}$ \\
\cline { 2 - 3 } & Negative & $\begin{array}{l}\text { From [bankname]: [name], To avoid penalty pls pay your } \\
\text { loan on time. If paid, pls ignore msg. Tnx. }\end{array}$ \\
\hline
\end{tabular}


Table 2. Summary Statistics (mean/standard error)

Content Treatment

\begin{tabular}{|c|c|c|c|c|c|c|c|c|c|}
\hline & \multirow{3}{*}{ Control } & \multirow{3}{*}{ Treatment } & \multicolumn{4}{|c|}{ Content Treatment } & \multicolumn{3}{|c|}{ Timing Treatment } \\
\hline & & & \multicolumn{2}{|c|}{ SMS addressed to client } & \multicolumn{2}{|c|}{ SMS signed by account officer } & \multicolumn{3}{|c|}{ Days SMS sent before payment due } \\
\hline & & & Positive & Negative & Positive & Negative & 0 & 1 & 2 \\
\hline \multicolumn{10}{|l|}{ Baseline loan characteristics } \\
\hline \multirow[t]{2}{*}{ Loan size (peso) } & 22141 & 25331 & 23040 & 25852 & 26485 & 25386 & 25571 & 25173 & 25227 \\
\hline & $(1530)$ & $(1488)$ & $(1894)$ & $(2614)$ & $(3286)$ & $(3676)$ & $(2228)$ & $(2301)$ & $(3094)$ \\
\hline \multirow[t]{2}{*}{ Loan term (weeks) } & 19.1 & 19.7 & 19.0 & 20.8 & 19.0 & 19.0 & 20.1 & 19.6 & 19.3 \\
\hline & $(0.7)$ & $(0.5)$ & $(1.0)$ & $(0.9)$ & $(1.0)$ & $(0.8)$ & $(0.8)$ & $(0.8)$ & $(0.8)$ \\
\hline \multirow[t]{2}{*}{ Number of weeks in experiment } & 10.6 & 10.6 & 10.2 & 10.6 & 10.9 & 10.6 & 10.6 & 10.9 & 10.4 \\
\hline & $(0.3)$ & $(0.2)$ & $(0.4)$ & $(0.4)$ & $(0.4)$ & $(0.5)$ & $(0.4)$ & $(0.4)$ & $(0.3)$ \\
\hline p-value from F-test verifying orthogonality & & 0.587 & & 0.718 & 0.170 & 0.856 & 0.331 & 0.662 & \\
\hline \multicolumn{10}{|c|}{ Outcome variables: proportion of all weekly payments } \\
\hline \multirow[t]{2}{*}{ Late } & 0.287 & 0.296 & 0.302 & $0.335^{*}$ & $0.231^{*}$ & 0.291 & 0.292 & 0.302 & 0.293 \\
\hline & $(0.018)$ & $(0.013)$ & $(0.032)$ & $(0.022)$ & $(0.026)$ & $(0.027)$ & $(0.023)$ & $(0.023)$ & $(0.023)$ \\
\hline \multirow[t]{2}{*}{ More than 1 day late } & 0.252 & 0.251 & 0.270 & 0.280 & $0.190^{* *}$ & 0.249 & 0.248 & 0.257 & 0.249 \\
\hline & $(0.018)$ & $(0.013)$ & $(0.031)$ & $(0.021)$ & $(0.025)$ & $(0.026)$ & $(0.022)$ & $(0.023)$ & $(0.021)$ \\
\hline \multirow[t]{2}{*}{ More than 7 days late } & 0.156 & 0.153 & 0.175 & 0.171 & $0.110^{*}$ & 0.148 & 0.154 & 0.156 & 0.148 \\
\hline & $(0.016)$ & $(0.011)$ & $(0.029)$ & $(0.019)$ & $(0.022)$ & $(0.024)$ & $(0.019)$ & $(0.021)$ & $(0.020)$ \\
\hline \multicolumn{10}{|l|}{ Outcome variables:loan at maturity } \\
\hline \multirow[t]{2}{*}{ Any unpaid balance at maturity } & 0.235 & 0.217 & 0.241 & 0.260 & $0.134^{* * *}$ & 0.210 & 0.210 & 0.210 & 0.229 \\
\hline & $(0.024)$ & $(0.016)$ & $(0.040)$ & $(0.029)$ & $(0.029)$ & $(0.034)$ & $(0.028)$ & $(0.029)$ & $(0.028)$ \\
\hline \multirow[t]{2}{*}{ Any unpaid balance at maturity +30 days } & 0.135 & 0.098 & 0.121 & 0.134 & $0.035^{* * *}$ & $0.084^{*}$ & 0.103 & $0.082^{*}$ & 0.108 \\
\hline & $(0.019)$ & $(0.012)$ & $(0.030)$ & $(0.022)$ & $(0.016)$ & $(0.023)$ & $(0.021)$ & $(0.020)$ & $(0.021)$ \\
\hline Number loans & 311 & 632 & 116 & 231 & 142 & 143 & 214 & 195 & 223 \\
\hline
\end{tabular}

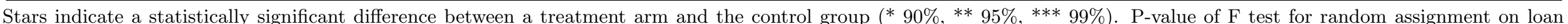
characteristics includes controls for account officer and month-year fixed effects. 
Table 3. Ols Treatment Effect Estimates for Messaging, Content, and Timing

\begin{tabular}{|c|c|c|c|c|c|c|c|c|c|}
\hline \multirow{3}{*}{$\begin{array}{l}\text { Unit of observation } \\
\text { Any SMS }\end{array}$} & \multicolumn{3}{|c|}{$\begin{array}{c}\text { Late } \\
\text { Weekly payment }\end{array}$} & \multicolumn{3}{|c|}{$\begin{array}{c}\text { More than } 7 \text { days late } \\
\text { Weekly payment }\end{array}$} & \multicolumn{3}{|c|}{$\begin{array}{c}\text { Any unpaid balance at maturity }+30 \text { day } \\
\text { Loan }\end{array}$} \\
\hline & \multicolumn{6}{|c|}{ Panel A: Content } & & & \\
\hline & $\begin{array}{l}-0.007 \\
(0.021)\end{array}$ & & $\begin{array}{c}0.024 \\
(0.025)\end{array}$ & $\begin{array}{l}-0.004 \\
(0.019)\end{array}$ & & $\begin{array}{c}0.020 \\
(0.023)\end{array}$ & $\begin{array}{l}-0.024 \\
(0.023)\end{array}$ & & $\begin{array}{l}-0.000 \\
(0.027)\end{array}$ \\
\hline Positive frame X SMS addressed to client & \multicolumn{3}{|c|}{$\begin{array}{c}0.008 \\
(0.036)\end{array}$} & \multicolumn{3}{|c|}{$\begin{array}{c}0.010 \\
(0.031)\end{array}$} & \multicolumn{3}{|c|}{$\begin{array}{c}0.005 \\
(0.035)\end{array}$} \\
\hline Negative frame X SMS addressed to client & \multicolumn{3}{|c|}{$\begin{array}{c}0.032 \\
(0.028)\end{array}$} & \multicolumn{3}{|c|}{$\begin{array}{c}0.025 \\
(0.025)\end{array}$} & \multicolumn{3}{|c|}{$\begin{array}{l}-0.003 \\
(0.031)\end{array}$} \\
\hline Positive frame X SMS signed by account officer & \multicolumn{3}{|c|}{$\begin{array}{c}-0.065^{* *} \\
(0.028)\end{array}$} & \multicolumn{3}{|c|}{$\begin{array}{c}-0.044^{*} \\
(0.024)\end{array}$} & \multicolumn{3}{|c|}{$\begin{array}{c}-0.078^{* * *} \\
(0.025)\end{array}$} \\
\hline Negative frame X SMS signed by account officer & \multicolumn{3}{|c|}{$\begin{array}{l}-0.025 \\
(0.028)\end{array}$} & \multicolumn{3}{|c|}{$\begin{array}{l}-0.021 \\
(0.023)\end{array}$} & \multicolumn{3}{|c|}{$\begin{array}{l}-0.029 \\
(0.031)\end{array}$} \\
\hline AO name & \multicolumn{3}{|r|}{$\begin{array}{c}-0.069^{* * *} \\
(0.024)\end{array}$} & \multicolumn{3}{|r|}{$\begin{array}{c}-0.052^{* *} \\
(0.021)\end{array}$} & \multicolumn{3}{|r|}{$\begin{array}{c}-0.053^{* *} \\
(0.024) \\
\end{array}$} \\
\hline \multicolumn{10}{|c|}{ Panel B: Timing } \\
\hline Any SMS & $\begin{array}{l}-0.007 \\
(0.021)\end{array}$ & & $\begin{array}{c}0.024 \\
(0.025)\end{array}$ & $\begin{array}{l}-0.004 \\
(0.019)\end{array}$ & & $\begin{array}{c}0.020 \\
(0.023)\end{array}$ & $\begin{array}{l}-0.024 \\
(0.023)\end{array}$ & & $\begin{array}{l}-0.000 \\
(0.027)\end{array}$ \\
\hline SMS sent day payment due & \multicolumn{3}{|c|}{$\begin{array}{l}-0.011 \\
(0.027)\end{array}$} & \multicolumn{3}{|c|}{$\begin{array}{l}-0.000 \\
(0.025)\end{array}$} & \multicolumn{3}{|c|}{$\begin{array}{l}-0.012 \\
(0.030)\end{array}$} \\
\hline SMS sent 1 day before payment due & \multicolumn{3}{|c|}{$\begin{array}{l}-0.008 \\
(0.027)\end{array}$} & \multicolumn{3}{|c|}{$\begin{array}{l}-0.012 \\
(0.023)\end{array}$} & \multicolumn{3}{|c|}{$\begin{array}{l}-0.037 \\
(0.027)\end{array}$} \\
\hline SMS sent 2 days before payment due & \multicolumn{3}{|c|}{$\begin{array}{l}-0.003 \\
(0.027)\end{array}$} & \multicolumn{3}{|c|}{$\begin{array}{c}0.000 \\
(0.024)\end{array}$} & \multicolumn{3}{|c|}{$\begin{array}{l}-0.025 \\
(0.028)\end{array}$} \\
\hline AO name & & & $\begin{array}{c}-0.069^{* * *} \\
(0.024)\end{array}$ & & & $\begin{array}{c}-0.052^{* *} \\
(0.021)\end{array}$ & & & $\begin{array}{c}-0.053^{* *} \\
(0.024)\end{array}$ \\
\hline$\overline{\mathrm{AOFE}}$ & Yes & Yes & Yes & Yes & Yes & Yes & Yes & Yes & Yes \\
\hline Month-Year FE & Yes & Yes & Yes & Yes & Yes & Yes & Yes & Yes & Yes \\
\hline Mean control group & 0.291 & 0.291 & 0.291 & 0.158 & 0.158 & 0.158 & 0.135 & 0.135 & 0.135 \\
\hline Number repayments & 9994 & 9994 & 9994 & 9994 & 9994 & 9994 & . & . & . \\
\hline Number loans & 943 & 943 & 943 & 943 & 943 & 943 & 943 & 943 & 943 \\
\hline
\end{tabular}

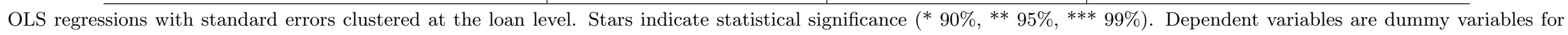
measures of late payment or outstanding balance at maturity. All regressions include controls for account officer and month-year fixed effects. 
Table 4. Monitoring or Reciprocity: First Time Clients vs Pre-Existing Clients

\begin{tabular}{|c|c|c|c|c|c|c|c|c|c|}
\hline \multirow{2}{*}{ Unit of observation } & \multicolumn{3}{|c|}{$\begin{array}{c}\text { Late } \\
\text { Weekly payment }\end{array}$} & \multicolumn{3}{|c|}{$\begin{array}{l}\text { More } 7 \text { days late } \\
\text { Weekly payment }\end{array}$} & \multicolumn{3}{|c|}{$\begin{array}{c}\text { Unpaid at maturity }+30 \text { day } \\
\text { Loan }\end{array}$} \\
\hline & \multicolumn{4}{|c|}{$\begin{array}{l}\text { Weekly payment } \\
\text { s who are first time borrowers from bank }\end{array}$} & & & & & \\
\hline Any SMS & $\begin{array}{c}0.005 \\
(0.031)\end{array}$ & & $\begin{array}{c}0.014 \\
(0.037)\end{array}$ & $\begin{array}{c}0.018 \\
(0.028)\end{array}$ & & $\begin{array}{c}0.027 \\
(0.033)\end{array}$ & $\begin{array}{l}-0.003 \\
(0.035)\end{array}$ & & $\begin{array}{c}0.009 \\
(0.040)\end{array}$ \\
\hline Positive frame X SMS addressed to client & \multicolumn{3}{|c|}{$\begin{array}{l}-0.080 \\
(0.053)\end{array}$} & \multicolumn{3}{|c|}{$\begin{array}{l}-0.038 \\
(0.042)\end{array}$} & \multicolumn{3}{|c|}{$\begin{array}{c}0.000 \\
(0.049)\end{array}$} \\
\hline Negative frame X SMS addressed to client & \multicolumn{3}{|c|}{$\begin{array}{c}0.054 \\
(0.040)\end{array}$} & \multicolumn{3}{|c|}{$\begin{array}{c}0.055 \\
(0.038)\end{array}$} & \multicolumn{3}{|c|}{$\begin{array}{c}0.012 \\
(0.046)\end{array}$} \\
\hline Positive frame X SMS signed by account officer & \multicolumn{3}{|c|}{$\begin{array}{l}-0.042 \\
(0.044)\end{array}$} & \multicolumn{3}{|c|}{$\begin{array}{l}-0.027 \\
(0.037)\end{array}$} & \multicolumn{3}{|c|}{$\begin{array}{l}-0.072 \\
(0.046)\end{array}$} \\
\hline Negative frame X SMS signed by account officer & \multicolumn{3}{|c|}{$\begin{array}{c}0.025 \\
(0.043)\end{array}$} & \multicolumn{3}{|c|}{$\begin{array}{c}0.036 \\
(0.035)\end{array}$} & \multicolumn{3}{|c|}{$\begin{array}{c}0.030 \\
(0.049)\end{array}$} \\
\hline AO name & & & $\begin{array}{l}-0.022 \\
(0.038)\end{array}$ & & & $\begin{array}{l}-0.021 \\
(0.032)\end{array}$ & & & $\begin{array}{l}-0.027 \\
(0.040)\end{array}$ \\
\hline Mean control group & 0.335 & 0.335 & 0.335 & 0.178 & 0.178 & 0.178 & 0.123 & 0.123 & 0.123 \\
\hline Number repayments & 4576 & 4576 & 4576 & 4576 & 4576 & 4576 & & & \\
\hline Number loans & 464 & 464 & 464 & 464 & 464 & 464 & 464 & 464 & 464 \\
\hline \multicolumn{10}{|c|}{ Panel B: Clients who have borrowed from bank before } \\
\hline Any SMS & $\begin{array}{l}-0.029 \\
(0.027)\end{array}$ & & $\begin{array}{c}0.020 \\
(0.033)\end{array}$ & $\begin{array}{l}-0.032 \\
(0.025)\end{array}$ & & $\begin{array}{c}0.007 \\
(0.031)\end{array}$ & $\begin{array}{c}-0.060^{*} \\
(0.033)\end{array}$ & & $\begin{array}{l}-0.021 \\
(0.040)\end{array}$ \\
\hline Positive frame X SMS addressed to client & & $\begin{array}{c}0.059 \\
(0.046)\end{array}$ & & & $\begin{array}{c}0.022 \\
(0.043)\end{array}$ & & & $\begin{array}{c}-0.002 \\
(0.051)\end{array}$ & \\
\hline Negative frame X SMS addressed to client & & $\begin{array}{l}-0.003 \\
(0.038)\end{array}$ & & & $\begin{array}{l}-0.002 \\
(0.035)\end{array}$ & & & $\begin{array}{l}-0.033 \\
(0.047)\end{array}$ & \\
\hline Positive frame X SMS signed by account officer & & $\begin{array}{c}-0.094^{* * *} \\
(0.036)\end{array}$ & & & $\begin{array}{c}-0.079^{* *} \\
(0.034)\end{array}$ & & & $\begin{array}{c}-0.110^{* * *} \\
(0.034)\end{array}$ & \\
\hline Negative frame X SMS signed by account officer & & $\begin{array}{l}-0.061^{*} \\
(0.033)\end{array}$ & & & $\begin{array}{c}-0.067^{* *} \\
(0.028)\end{array}$ & & & $\begin{array}{c}-0.095^{* *} \\
(0.042)\end{array}$ & \\
\hline AO name & & & $\begin{array}{c}-0.100^{* * *} \\
(0.031)\end{array}$ & & & $\begin{array}{c}-0.080^{* * *} \\
(0.029)\end{array}$ & & & $\begin{array}{c}-0.083^{* * *} \\
(0.032)\end{array}$ \\
\hline Mean control group & 0.248 & 0.248 & 0.248 & 0.137 & 0.137 & 0.137 & 0.148 & 0.148 & 0.148 \\
\hline Number repayments & 5418 & 5418 & 5418 & 5418 & 5418 & 5418 & & & \\
\hline Number loans & 485 & 485 & 485 & 485 & 485 & 485 & 479 & 479 & 479 \\
\hline p-value from F-test for equality of $\mathrm{AO}$ name coefficient over client type & & & 0.009 & & & 0.041 & & & 0.057 \\
\hline $\mathrm{AO} F$ & Yes & Yes & Yes & Yes & Yes & Yes & Yes & Yes & Yes \\
\hline Month-Year FE & Yes & Yes & Yes & Yes & Yes & Yes & Yes & Yes & Yes \\
\hline
\end{tabular}

OLS regressions with standard errors clustered at the loan level. Stars indicate statistical significance $(* 90 \%, * * 95 \%, * * * 99 \%)$. Dependent variables are dummy variables for measures of late payment or outstanding balance at maturity. All regressions include controls for account officer and month-year fixed effects.. P-value from F-test that the coefficients are the same from first-time and pre-existing clients, computed by estimating a pooled model with interaction term. 
Appendix Table 1. Ols Treatment Effect Estimates for Three Additional Repayment Measures

\begin{tabular}{|c|c|c|c|c|c|c|c|c|c|}
\hline \multirow{3}{*}{$\begin{array}{l}\text { Unit of observation } \\
\text { Any SMS }\end{array}$} & \multicolumn{3}{|c|}{$\begin{array}{l}\text { More } 1 \text { day late } \\
\text { Weekly payment }\end{array}$} & \multicolumn{3}{|c|}{$\begin{array}{c}\text { Missed week } \\
\text { Weekly payment }\end{array}$} & \multicolumn{3}{|c|}{$\begin{array}{c}\text { Unpaid at maturity } \\
\text { Loan }\end{array}$} \\
\hline & \multicolumn{3}{|c|}{ Panel A: Content } & & & & & & \\
\hline & $\begin{array}{l}-0.007 \\
(0.020)\end{array}$ & & $\begin{array}{c}0.023 \\
(0.025)\end{array}$ & $\begin{array}{l}-0.001 \\
(0.016)\end{array}$ & & $\begin{array}{c}0.021 \\
(0.020)\end{array}$ & $\begin{array}{l}-0.011 \\
(0.029)\end{array}$ & & $\begin{array}{c}0.019 \\
(0.035)\end{array}$ \\
\hline Positive frame X SMS addressed to client & \multicolumn{3}{|c|}{$\begin{array}{c}0.018 \\
(0.034)\end{array}$} & \multicolumn{3}{|c|}{$(0.027)$} & \multicolumn{3}{|c|}{$\begin{array}{c}0.044 \\
(0.047)\end{array}$} \\
\hline Negative frame X SMS addressed to client & \multicolumn{3}{|c|}{$\begin{array}{l}0.026 \\
(0.028)\end{array}$} & & $\begin{array}{c}0.024 \\
(0.022)\end{array}$ & & \multicolumn{3}{|c|}{$\begin{array}{c}0.005 \\
(0.039)\end{array}$} \\
\hline Positive frame X SMS signed by account officer & \multicolumn{3}{|c|}{$\begin{array}{c}-0.060^{* *} \\
(0.027)\end{array}$} & \multicolumn{2}{|c|}{$(0.022)$} & & \multicolumn{3}{|c|}{$\begin{array}{c}-0.080^{* *} \\
(0.038)\end{array}$} \\
\hline Negative frame X SMS signed by account officer & \multicolumn{3}{|c|}{-0.025} & \multirow{2}{*}{\multicolumn{3}{|c|}{$\begin{array}{c}-0.049^{* * *} \\
(0.019)\end{array}$}} & \multicolumn{3}{|c|}{$\begin{array}{l}-0.012 \\
(0.041)\end{array}$} \\
\hline AO name & & & $\begin{array}{c}-0.065^{* * *} \\
(0.023)\end{array}$ & & & & & & $\begin{array}{c}-0.065^{*} \\
(0.034) \\
\end{array}$ \\
\hline \multicolumn{10}{|c|}{ Panel B: Timing } \\
\hline Any SMS & $\begin{array}{l}-0.007 \\
(0.020)\end{array}$ & & $\begin{array}{c}0.023 \\
(0.025)\end{array}$ & $\begin{array}{l}-0.001 \\
(0.016)\end{array}$ & & $\begin{array}{c}0.021 \\
(0.020)\end{array}$ & $\begin{array}{l}-0.011 \\
(0.029)\end{array}$ & & $\begin{array}{c}0.019 \\
(0.035)\end{array}$ \\
\hline SMS sent day payment due & \multicolumn{3}{|c|}{$\begin{array}{l}-0.012 \\
(0.027)\end{array}$} & & -0.005 & & \multicolumn{3}{|c|}{$\begin{array}{l}-0.007 \\
(0.038)\end{array}$} \\
\hline SMS sent 1 day before payment due & \multicolumn{3}{|c|}{$\begin{array}{l}-0.010 \\
(0.026)\end{array}$} & & $\begin{array}{l}-0.006 \\
(0.020)\end{array}$ & & \multicolumn{3}{|c|}{$\begin{array}{l}-0.013 \\
(0.038)\end{array}$} \\
\hline SMS sent 2 days before payment due & \multicolumn{3}{|c|}{$\begin{array}{c}0.001 \\
(0.026)\end{array}$} & \multicolumn{3}{|c|}{$\begin{array}{c}0.008 \\
(0.021)\end{array}$} & \multicolumn{3}{|c|}{$\begin{array}{l}-0.012 \\
(0.036)\end{array}$} \\
\hline AO name & & & $\begin{array}{c}-0.065^{* * *} \\
(0.023)\end{array}$ & & & $\begin{array}{c}-0.049^{* * *} \\
(0.019)\end{array}$ & & & $\begin{array}{c}-0.065^{*} \\
(0.034) \\
\end{array}$ \\
\hline $\mathrm{AO} \mathrm{FE}$ & Yes & Yes & Yes & Yes & Yes & Yes & Yes & Yes & Yes \\
\hline Month-Year FE & Yes & Yes & Yes & Yes & Yes & Yes & Yes & Yes & Yes \\
\hline Mean control group & 0.252 & 0.252 & 0.252 & 0.185 & 0.185 & 0.185 & 0.235 & 0.235 & 0.235 \\
\hline Number repayments & 9994 & 9994 & 9994 & 9994 & 9994 & 9994 & . & . & . \\
\hline Number loans & 943 & 943 & 943 & 943 & 943 & 943 & 943 & 943 & 943 \\
\hline
\end{tabular}

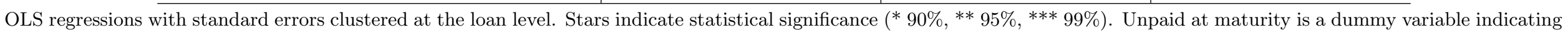
whether loan has been fully repaid. All regressions include controls for account officer and month-year fixed effects. Missed week is a missed calendar week. 


\section{Appendix Table 2. Ols Treatment Effects By Framing Treatment}

\begin{tabular}{|c|c|c|c|}
\hline Unit of observation & $\begin{array}{c}\text { Late } \\
\text { Weekly payment }\end{array}$ & $\begin{array}{l}\text { More than } 7 \text { days late } \\
\text { Weekly payment }\end{array}$ & $\begin{array}{c}\text { Any unpaid balance at maturity }+30 \text { day } \\
\text { Loan }\end{array}$ \\
\hline Positive framing & 0.010 & 0.007 & -0.014 \\
\hline & $(0.023)$ & $(0.021)$ & $(0.026)$ \\
\hline Negative framing & -0.033 & -0.020 & -0.040 \\
\hline & $(0.025)$ & $(0.022)$ & $(0.025)$ \\
\hline $\mathrm{AOFE}$ & Yes & Yes & Yes \\
\hline Month-Year FE & Yes & Yes & Yes \\
\hline P-value from F-test for equality of framing coefficients & 0.082 & 0.188 & 0.259 \\
\hline Mean control group & 0.291 & 0.158 & 0.135 \\
\hline Number repayments & 9994 & 9994 & . \\
\hline Number loans & 943 & 943 & 943 \\
\hline
\end{tabular}

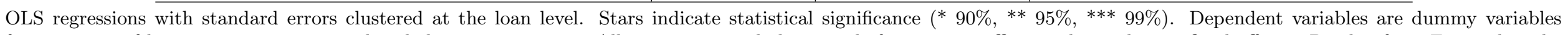

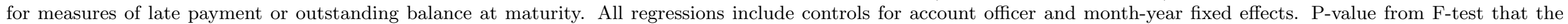
coefficients on negative framing and positive framing are the same. 